\title{
Deskripsi Konseli pada Proses Konseling: Refleksi Al Qur’an Surah Asy Syams
}

\author{
Karyono Ibnu Ahmad, ${ }^{1}$ Muhammad Andri Setiawan ${ }^{2}$ \\ ${ }^{1,2}$ Universitas Lambung Mangkurat Banjarmasin \\ andri.bk@ulm.ac.id
}

Submitted: 06-04-2018, Revised: 20-05-2018, Accepted: 20-06-2018

\begin{abstract}
This article aims to examine the description of counselee in the counseling process according to Surah Asy Syams, which is based on the author's reflection during counseling practice using the Qur'an media. Researchers found that counselees in the counseling process generally divided into three broad categories namely, (1) counselee based on growth and development level expressed based on sura Al Mukmin verse 67; (2) a special treatment counsel to women, referring to the Bukhari and Muslim narrated by Abu Hurairah Ra who calls women a crooked rib; and (3) the last counselor with special needs refers to Abasa 'verses 1-11. The counselee description in the counseling process based on the surah Asy Syams is divided into three parts: (1) the counselee has not understood the obstacles of his whole (sura Asy Shams verses 1-6); (2) the counselee when he finds out how to solve the obstacles he experienced (sura Asy Shams verses 7-10); and finally, the condition of the counselee who does not want to change the obstacles he experienced by analogizing the Thamud experienced (Surah Asy Syams verses 11 through 15).
\end{abstract}

Keywords: Counselor; Counselee; Counseling Process

\begin{abstract}
Abstrak: Artikel ini bertujuan menelaah deskripsi konseli dalam proses konseling menurut surah Asy Syams, yang didasari refleksi penulis selama melakukan praktik konseling dengan menggunakan media Al Qur'an. Peneliti menemukan bahwa konseli dalam proses konseling secara umum terbagi dalam tiga kategori besar yakni,(1) konseli yang didasari tingkatan pertumbuhan dan perkembangan yang diungkapkan berdasarkan surah Al Mukmin ayat 67; (2) konseli perlakuan khusus kepada wanita, yang mengacu pada hadist Bukhari dan Muslim yang diriwayatkan Abu Hurairah Ra yang menyebut wanita adalah tulang rusuk yang bengkok; dan (3) terakhir konseli yang berkebutuhan khusus mengacu pada surah Abasa' ayat 1-11. Adapun deskripsi konseli dalam proses konseling didasari pada surah Asy Syams terbagi ke dalam tiga bagian: (1) konseli belum memahami hambatan dirinya secara utuh (surah Asy Syams ayat 1-6); (2) konseli ketika menemukan cara menyelesaikan hambatan yang dialaminya (surah Asy Syams ayat 7-10); dan terakhir, kondisi konseli yang tidak mau mengubah hambatan yang dialaminya dengan menganalogikan kaum Tsamud dialaminya (surah Asy Syams ayat 11 sampai ayat 15).

Kata Kunci : Konselor; Konseli; Proses Konseling
\end{abstract}

\section{Pendahuluan}

Proses konseling merupakan proses yang melibatkan kondisi psikologis yang dihadapkan seseorang melalui hubungan yang bersifat profesional dan tidak hanya dilandasi hubungan pribadi. Seseorang yang dimaksud sudah tentu adalah mereka yang terlibat secara aktif mengikuti proses konseling atau diistilahkan sebagai konseli. Proses konseling terjadi karena adanya keingin konseli menyelesaikan hambatan kehidupan yang ia alami. Hambatan tersebut tercermin ke dalam harapan yang diinginkan konseli dalam proses konseling (Saccazzo dalam Latipun, 2015: 44).

Hal ini sejalan dengan pelaksanaan konseling yang tentunya memandang bahwa setiap konseli hendaknya mendapatkan perlakuan konseling yang sama sesuai dengan karakteristik mereka masing-masing. Merujuk pada pendefinisian proses konseling, maka McLead (2008: 363-365) membaginya empat makna utama pelaksanaan konseling dipandang sebagai proses yakni: Pertama, pemahaman luas pada setiap aktivitas yang melibatkan perubahan diri dalam konseling tidak statis dan bersifat dinamis; Kedua, pada literatur riset merujuk pada serangkaian faktor yang menghambat efek terapeutik konseling terhadap konseli; Ketiga, konseling dianggap proses kualitas esensial manusia, dan terakhir keempat, deskripsi cara konseli dalam memahami atau mengasimilasi pengalaman sulit. 
Brammer (Willis, 2014: 50) mengeluarkan pernyataan yang senada dengan menyebut proses konseling sebagai peristiwa yang memberi makna konseli. Namun hal lain yang perlu difahami juga bahwa pelaksanaan proses konseling dalam memberikan makna bagi peserta konseling tidak terlepas dari sistem nilai keyakinan (belief system) yang dianut serta bagaimana pendekatan konseling yang dianut berdasarkan interprestasi dan refleksi konselor yang bersangkutan sehingga akan muncul kebermaknaan konseling sebagaimana yang diharapkan. Sanyata (2006) mengungkapkan kebermaknaan proses konseling merupakan sentral layanan konseling.

Berangkat dari uraian di atas, maka penulis mengangkat upaya mendeskripsikan konseli dalam proses konseling dengan mendasari pada refleksi penulis atas pengalaman berpraktek melakukan pendekatan bimbingan dan konseling Qur'ani. Pendeskripsian konseli pada proses konseling mengacu pada Al Qur'an surah Asy Syams.

\section{Metode Penelitian}

Metode penelitian ini dilakukan dengan deskriptif kualitatif dalam tulisan ini peneliti menggunakan studi pustaka atau menggali data dari library research dan juga didasari refleksi pengalaman berpraktek melakukan konseling dengan menggunakan media Al Qur'an.

\section{Hasil dan Pembahasan \\ Memaknai Konseli Secara Umum}

Pelaksanaan proses konseling bagi seorang konselor akan menyadari adanya eksistensi konseli yang dapat dikatakan beragam, individualis sekaligus unik dan inilah yang akan dihadapi oleh konselor karena:

1. Dikatakan beragam karena konseli yang ditangani konselor bermacam-macam ragam karakter, kebiasaan dan perilakunya dalam proses konseling.

2. Dikatakan individualis karena masing-masing konseli dalam proses konseling memiliki sejumlah perbedaan yang khas sehingga dalam perlakuan dan pembimbingan tidak dapat disamakan satu sama lain meskipun konseli tersebut pada kadar tertentu memiliki kesamaan orientasi.

3. Dikatakan unik karena konseli tersebut dalam menyampaikan dan mengilustrasikan keadaan dirinya serta cara konseli menghadapi lingkungan berbeda.

Konselor akan mampu menangkap semua eksistensi konseli yang dimaksud sebagai pribadi dan bukan sebagai obyek (Tirtawati, 2017). Pada hubungan antar pribadi kedudukan adalah setara yang didapat konselor dalam membangun metakognisi, seperti diungkapkan oleh Radjah (2016: 93) yang menyebut metakognisi konselor meliputi: penciptaan peraturan, persepsi, self talk, citra visual, penjelasan dan pengharapan.

Hal-hal tersebutlah menjadi kesulitan penulis selama berpraktek dalam memaknai kemauan dan ragam konseli dalam proses konseling. Namun selama proses konseling tersebut memiliki orientasi penyelesaian hambatan dengan konseli dalam kehidupan sehari-hari, maka tidak akan menjadi permasalahan mendasar, tatkala penulis mengembalikan penyelesaian permasalahan konseli kepada Allah Swt melalui media Al Qur'an sebagai media terapeutik. Justru dalam proses penulis berpraktek selama ini kami menyadari Al Qur'an sangat mampu menangkap getar-getar permasalahan konseli pada proses konseling dan hal ini penulis temukan melalui refleksi pada keseluruhan surah Asy Syams.

\section{Penjelasan Al Qur'an Surah Asy Syams tentang Manusia}

Surah Asy Syams terdiri dari 15 ayat, termasuk kelompok surah Makkiyah. Nama Asy Syams diambil dari kata pertama dari ayat pertama yang berarti matahari. Adapun isi keseluruhan dari surah Asy Syams adalah sebagai berikut. 
(1) Demi matahari dan cahayanya di pagi hari (2) dan bulan apabila mengiringinya (3) dan siang apabila menampakkannya (4) dan malam apabila menutupinya (5) dan langit serta pembinaannya (6) dan bumi serta penghamparannya (7) dan jiwa serta penyempurnaannya (ciptaannya) (8) maka Allah mengilhamkan kepada jiwa itu (jalan) kefasikan dan ketakwaannya (9) sesungguhnya beruntunglah orang yang mensucikan jiwa itu (10) dan sesungguhnya merugilah orang yang mengotorinya (11) (Kaum) Tsamud telah mendustakan (rasulnya) karena mereka melampaui batas (12) ketika bangkit orang yang paling celaka di antara mereka (13) lalu Rasul Allah (Saleh) berkata kepada mereka: ("Biarkanlah) unta betina Allah dan minumannya" (14) Lalu mereka mendustakannya dan menyembelih unta itu, maka Tuhan mereka membinasakan mereka disebabkan dosa mereka, lalu Allah menyama-ratakan mereka (dengan tanah) (15) dan Allah tidak takut terhadap akibat tindakan-Nya itu (QS. Asy Syams [91]: 1-15).

Menurut penafsiran Kementerian Agama RI (2010: 678-679 dan 681) surah tersebut terbagi dalam dua kategori pembahasan. Pada pembahasan pertama yakni terdiri dari ayat pertama sampai dengan ayat ke sepuluh, membicarakan tentang manusia yang diberikan Allah potensi jahat dan baik. Dalam pembahasan pertama ini secara garis besar mengungkapkan bahwa Allah menciptakan makhluk-Nya berpasangan, begitu juga kenyataannya dengan pribadi manusia.

Sedangkan pada pembahasan kedua dari ayat ke sebelas hingga ayat ke limabelas yang berbicara mengenai contoh manusia celaka adalah kaum Tsamud. Kaum Tsamud seperti disebutkan memandang kerasulan nabi Saleh As dan mukjizat yang diberikan Allah kepadanya bohong. Kaum Tsamud membunuh unta betina dijadikan Allah sebagai mukjizat Saleh As. Karena pembangkangan itu, Allah menghancurkan mereka yang dianggap menentang ketentuan-ketentuan yang digariskan Allah akan membawanya kepada kesengsaraan.

\section{Refleksi Surah Asy Syams tentang Konseli dalam Proses Konseling}

Mengikut perkembangan konseli dalam proses konseling, penulis menemukan bahwa secara garis besar konseli terbagi ke dalam tiga klasifikasi besar yakni sebagai berikut:

1. Memperhatikan konseli dengan mempertimbangkan tingkat perkembangan konseli sebagai manusia yang mengalami tumbuh kembang sehingga konseli tersebut menyadari potensi dan kebutuhan diri yang dimilikinya. Al Qur'an dalam surah Al Mukmin ayat 67 menyebutkan kaedah ini.

Dialah yang menciptakan engkau dari tanah kemudian dari setetes mani, sesudah itu dari segumpal darah, kemudian dilahirkannya engkau sebagai seorang anak, kemudian (engkau dibiarkan hidup) supaya engkau sampai kepada masa (dewasa), kemudian (dibiarkan engkau hidup lagi) sampai tua, di antara engkau ada yang diwafatkan sebelum itu. (Kami perbuat demikian) supaya engkau sampai kepada ajal yang ditentukan dan supaya engkau memahami(nya) (QS. Al Mukmin [40]: 67).

Ayat ini sebenarnya menerangkan bahwa manusia memiliki tumbuh kembang baik secara psikis maupun fisik, pada konteks proses konseling, konselor berhadapan dengan konseli yang memiliki kebutuhan yang beragampula. Hal ini sebagaimana diuraikan oleh Yusuf LN (2004: 15-16) menerangkan bahwa perkembangan diartikan sebagai perubahan sistematis, progresif dan kontinu dalam diri individu.

a. Secara sistematis, berarti perubahan dalam perkembangan itu bersifat saling mempengaruhi antara bagian-bagian organisme (fisik dan psikis) dan merupakan satu kesatuan yang harmonis.

b. Secara progresif, berarti perubahan yang terjadi bersifat maju, meningkat dan mendalam (meluas) baik secara kuantitatif (fisik) maupun kualitatif (psikis) dan terakhir, 
c. Secara berkesinambungan, berarti perubahan pada bagian atau fungsi terjadi secara kebetulan atau loncat-loncat

2. Memperhatikan kebutuhan wanita sebagai konseli tentu berbeda dengan konseli pria yang datang kepada konselor. Terdapat sejumlah pertimbangan proses bimbingan dan konseling, dikatakan oleh Rasulullah Saw dalam sebuah hadist yang diriwayatkan dari Abu Hurairah Ra, katanya Nabi Saw, bersabda: “.............Bijaksanalah membimbing wanita, karena wanita itu diciptakan dari tulang rusuk. Dan bahagianya yang paling bengkok ialah yang sebelah atas. Jika engkau berusaha meluruskannya, niscaya dia patah. Tetapi jika engkau biarkan, dia akan senantiasa bengkok. Karena itu bijaksanalah membimbing wanita dengan baik." (HR. Muslim).

Pada konteks proses konseling memaknai perempuan dalam proses konseling perlu dibimbing dengan penuh kebijaksanaan yakni dengan tidak memaksakan dan tidak pula terlalu lembut namun dengan memberikan perhatian yang sewajarnya. Tentunya dalam proses konseling kemampuan menarik hikmah dalam suatu peristiwa yang dialami konseli bersangkutan akan menjadi titik fokus yang menarik. Menurut penjelasan Kartono (2006: 1518) bahwa sifat kekhasan wanita diantaranya adalah perbedaan ekspresi tingkahlaku. Dalam bekerja para wanita cenderung mengeluarkan energi kerja yang berlebihan atau bekerja terlalu berat (overworked) karena dorongan kesadaran yang mendalam akan pentingnya tugas kewajiban secara lebih emosional. Wanita di tengah kehidupan sosial kemasyarakatan cenderung bersikap pasif dan lebih memilih pola tingkahlaku lebih mengalah terhadap pria sebagai suatu mekanisme membela diri ditengah masyarakat yang didominasi oleh pria pada umumnya.

3. Konseli yang memiliki kebutuhan khusus pada kenyataannya memiliki kekhasan yang berbeda dengan konseli pada umumnya terutama dalam membangun sosio-emosi ketika berinteraksi dan keragaman perspektif, kita dapat berkaca pada surah Abasa' ayat 1 hingga ayat 11 .

Dia (Muhammad) bermuka masam dan berpaling karena telah datang seorang buta kepadanya. Tahukah engkau barangkali ia ingin membersihkan dirinya (dari dosa) atau dia (ingin) mendapatkan pengajaran, lalu pengajaran itu memberi manfaat kepadanya. Adapun orang yang merasa dirinya serba cukup maka engkau melayaninya. Padahal tidak ada (celaan) atasmu kalau dia tidak membersihkan diri (beriman). Dan adapun orang yang datang kepadamu dengan bersegera (untuk mendapatkan pengajaran) sedang ia takut kepada (Allah) maka engkau mengabaikannya. Sekali-kali jangan (demikian)! Sesungguhnya ajaran-ajaran Tuhan itu adalah suatu peringatan (QS. Abasa' [80]: 1-11).

Ayat ini diturun kepada Rasulullah Saw sebagai teguran kepada beliau ketika datang Abdullah Bin Ummi Maktum seorang penyandang tunetra yang meminta kepada Nabi Saw memberikan sejumlah pelajaran tentang ajaran Islam. Sayangnya kala itu Rasulullah Saw lebih memperhatikan kaum pemuka kafir Quraisy (Kementerian Agama RI, 2010: 548). Disinilah Allah Swt memberi penghargaan baiknya bagaimana memperlakukan seseorang yang membutuhkan bimbingan yakni diawali kesadaran pribadinya untuk berubah dan menyadari keberadaan ajaran Islam maka ia akan lebih baik dibandingkan mereka yang sempurna namun tidak mempergunakan akalnya menerima kebenaran. Hanya saja hal yang membedakan konseli pada umumnya dengan konseli memiliki kebutuhan khusus adalah bentuk perlakuannya. Sebagaimana diungkapkan oleh Deplhie (2005: 94) merumuskan ada empat tujuan bimbingan pengembangan perilaku non-adaptif siswa tunagrahita ditingkat sekolah dasar. Empat tujuan yang dimaksud adalah sebagai berikut:

1. Membantu siswa secara sosio-emosional melalui transisi lingkungan.

2. Membantu siswa dapat mengatasi kesulitan-kesulitan yang dihadapinya.

3. Membantu siswa memahami keadaan dirinya dan lingkungan hidupnya. 
4. Membantu orangtua siswa yang bersangkutan dalam memahami anaknya.

Setelah kita memiliki gambaran utuh tentang konseli yang seperti apa yang kita hadapi dalam proses konseling terkait dengan aspek perilakunya, maka selanjutnya adalah mendudukkan deskripsi konseli dalam proses konseling sesuai dengan surah Asy Syams.

1. Pada konteks permulaan ayat 1 sampai dengan ayat ke 6 mengungkapkan eksistensi konseli dalam proses konseling dalam bentuk ilustrasi.

Pada konteks ini deskripsi konseli dalam proses konseling secara refleksi rohani terhadap perkembangan kondisi psikis konseli berada pada kondisi kebingungan dan ketikdatahuan yang ditampakkan oleh kondisi malam hari. Sebenarnya 'jalur' penyelesaian berada ditangan mereka sendiri namun mereka kesulitan menemukannya sehingga konseli seolah-olah berjalan dalam kegelapan. Hal ini sebenarnya dapat diatasi dengan cara konseli tersebut dibimbing untuk menemukan pencerahan yang sempurna secara bertahap atau membuka jalan berpikir. Secara bertahap proses konseling yang berjalan sesuai dengan harapan konseli dan konselor akan menemukan kenyataan penyelesaian hambatan dengan baik, sebagaimana malam bergerak menuju siang, yang sebelumnya terlihat sempit dan gelap menjadi terang dan terhampar luas. Kondisi inilah yang kemudian dinamakan oleh Thomas (1999: 94) sebagai penyesuaian yang beradaptasi dengan konteks, keyakinan, dan kebutuhan mereka.

2. Pada ayat 7 sampai ayat 10 dalam surah Asy Syams, diungkapkan secara tegas dan jelas tentang kondisi psikis yang dimaksud.

Terkait dengan menemukan cahaya yang terhampar pada deskripsi konseli dalam proses konseling pada ayat 1 sampai ayat 6 di atas, maka pada ayat ini tergambar reaksi konseli setelah menemukan titik terang penyebab hambatan yang dialaminya. Hambatan tersebut akan berhadapan dengan kemungkinan penyelesaian, maka untuk selanjutnya adalah reaksi konseli terhadap hambatan tersebut. Apakah kemudian ia mau mengubah hambatan tersebut dengan titik temu penyelesaian yang ada atau dia tetap bertahan dengan hambatan yang dimilikinya. Namun sesungguhnya hal tersebut dikembalikan kepada konseli itu sendiri. Semua ini, sebenarnya terjadi atas kehendak Allah Swt semata.

3. Di ayat 11 sampai ayat ke 15, dikemukakan contoh mereka yang memilih untuk tidak mau mengubah hambatan yang ia hadapi dengan penyelesaian yang telah diberikan.

Kecenderungan untuk tidak menerapkan upaya menyelesaikan hambatan sama halnya dengan contoh kaum Tsamud yang telah diberikan contoh yang nyata namun sebagian mereka tidak beriman dan berkeyakinan kepada jalan kebenaran. Sikap ini pada akhirnya akan merugikan diri mereka sendiri nantinya dan sudah tentu akan mendatangkan kesusahan bagi yang bersangkutan. Berhubungan dengan proses konseling maka penyelesaian hambatan sebenarnya adalah upaya untuk menemukan kebenaran yang hakiki karena sikap konseli yang mungkin telah menyimpang dari apa yang digariskan oleh Allah Swt, terutama apabila dihubungkan dengan perspektif ajaran Islam atau dengan bimbingan dan konseling menggunakan pendekatan Islami.

\section{Simpulan dan Saran}

Secara umum didapat sejumlah kesimpulan dan saran dari rangkaian penjelasan artikel di atas, yakni sebagai berikut.

1. Dalam proses konseling konselor akan menghadapi berbagai ragam konseli yang umumnya terbagi ke dalam tiga klasifikasi utama yakni konseli berdasarkan pertumbuhan dan perkembangannya, konseli wanita yang perlu diberikan perhatian kebutuhannya secara psikis dan terakhir konseli yang berkubtuhan khusus. 
2. Pada perspektif surah Asy Syams deskripsi konseli dalam proses konseling, terbagi ke dalam tiga bagian, yakni sebagai berikut.

a. Konseli ketika belum memahami hambatan akan penyelesaian masalahnya (surah Asy Syams ayat 1 sampai ayat 6 ).

b. Konseli ketika menemukan cara menyelesaikan hambatan yang dialaminya (surah Asy Syams ayat 7 sampai ayat 10 ).

c. Dipaparkan kondisi konseli yang tidak mau mengubah hambatan yang dialaminya dengan menganalogikan kaum Tsamud dialaminya (surah Asy Syams ayat 11 sampai ayat 15).

3. Artikel ini didasari pada refleksi surah Asy Syams atas deskripsi kondisi konseli dalam proses konseling belum mengarah pada riset praktisi secara menyeluruh, maka ke depannya dimungkinkan riset berkesinambungan terutama tentang topik terkait.

\section{Daftar Pustaka}

Al Qur'an

Deplhie, Bandi. (2005). Bimbingan dan Konseling untuk Perilaku Non-Adaptif. Bandung: Pustaka Bani Quraisy.

Kartono, Kartini. (2006). Psikologi Wanita 1: Mengenal Gadis Remaja dan Wanita Dewasa. Bandung: CV. Mandar Maju.

Kementerian Agama RI. (2010). Al Qur'an dan Tafsirnya Jilid X: Juz 28, 29, 30. Jakarta: Lentera Abadi.

McLeod, John. (2008). Pengantar Konseling: Teori dan Studi Kasus. Terjemahan A.K. Anwar dan diedit Tri Wibowo B.S. Jakarta: Kencana.

Muslim, Al Imam. (2005). Terjemahan Hadits Sahih Muslim Jilid 1, 2, 3, 4. Terjemahan Ma'mur Daud. Kuala Lumpur: KBC.

Radjah, Carolina L. (2016). 'Keterampilan Konseling Berbasis Metakognisi.' Jurnal Kajian Bimbingan dan Konseling, 1(3): 90-94.

Sanyata, Sigit. (2006). 'Perspektif Nilai dalam Konseling: Membangun Interaksi Efektif antara Konselor-Klien.' Paradigma, 2(1), Juli: 75-84.

Thomas, Frank. (1999). 'Competency-Based Relationship Counseling: The Necessity of Goal Setting and Counselor Flexibility in Efficient and Effective Couples Counseling.' The Journal of Pastoral Care, 53 (1), Spring: 87-99.

Tirtawati, Anak Agung Rai. (2017).'Pentingnya Kualitas Hubungan antar Pribadi Konselor dalam Konseling Realitas.' Jurnal Kajian Pendidikan Widya Accarya FKIP Universitas Dwijendra, Maret: 1-19.

Willis, Sofyan S. (2014). Konseling Individual: Teori dan Praktek. Bandung: Alfabeta.

Yusuf LN, Syamsu. (2004). Psikologi Perkembangan Anak dan Remaja. Bandung: Rosdakarya. 